\title{
ПРОБЛЕМИ УПРАВЛІННЯ
}

УДК 005.332.8

\author{
Й. М. Петрович, О. О. Трут ${ }^{1}$ \\ Національний університет "Львівська політехніка", \\ кафедра менеджменту організацій \\ ${ }^{1}$ Львівський торговельно-економічний університет
}

\section{МОНІТОРИНГ ІНДИВІДУАЛЬНОЇ РЕЗУЛЬТАТИВНОСТІ ПРАЦІВНИКІВ У ПРОЦЕСІ УПРАВЛІННЯ ОРГАНІЗАЦІЮ}

https://doi.org/10.23939/semi2019.03.073

(ㄱ Петрович Й. М., Трут О. О., 2019

У статті обгрунтовано цілі моніторингу індивідуальної результативності працівників у процесі управління організацісю. Розкрито процедуру та алгоритм ії оцінювання. Висвітлено принципи та вимоги до системи оцінювання результативності працівників. Визначено структуру і зміст профілю посади. Охарактеризовано інформаційне забезпечення процесу моніторингу результативності працівників. Аргументовано використання матричного методу оцінювання результативності працівників. Доведено забезпечення зворотного зв'язку під час управління результативністю як необхідної умови моніторингу індивідуальної результативності працівників.

Ключові слова: індивідуальна результативність, менеджер, моніторинг, організація, оцінювання, працівник, процес, результат, система, управління, цілі.

\author{
Y. Petrovych, O. Trut ${ }^{1}$ \\ Lviv Polytechnic National University \\ Department of Management of Organizations, \\ ${ }^{1}$ Lviv University of Trade and Economics
}

\section{MONITORING THE INDIVIDUAL RESULT OF THE EMPLOYEES IN THE ORGANIZATION MANAGEMENT PROCESS}

(C) Petrovych Y., Trut O., 2019

Managing the effectiveness of the organization is one of the main functions of the professional activities of the newest Ukrainian managers. Managing the effectiveness of the organization is a continuous process that logically covers the actions and procedures of the linear manager in a single chain according to the logic of meaningful activity: from the formulation of goals to control the achieved results. The main consequence of the evolution of performance management over the last decade is to focus not only on goals but also on means.

In the course of the study it is envisaged to study and generalize scientific approaches regarding the role and content of monitoring the individual performance of employees in the process of managing the organization.

The system for evaluating individual performance involves continuous monitoring of performance, which should be guided by agreed objectives, work plans, personnel development and improvement of its business processes. Most scholars believe that the ongoing monitoring process determines the informal discussion of the results achieved, formal interim inspections, and official attestations. Attestation of employees for the effectiveness is aimed at motivation, staff development, communication.

Management of individual performance, in particular, and its monitoring should be based on an agreement between the manager and employee. The agreement describes the 
objectives of the employee and how to measure the results of this work, fixes the agreed direction of development, forms the basis for measurements, feedback, evaluation and development of employees. The agreements formulate expectations - the results to be achieved and the skills, knowledge and experience necessary to achieve them. At the stage of employee performance planning, it is agreed on what criteria will be used for evaluating the effectiveness and what the actual data will serve as the basis for determining the levels of competencies.

Expectations should be clearly defined and coordinated in the form of job profiles. The profile should describe the current tasks in the form of requirements for each essential component of work in a particular position. It also targets from short to medium term, in terms of expanding skills and knowledge, alignment with the core values of the organization, and the fulfillment of the requirements for employee behavior. Throughout the year, especially during interim inspections, it is necessary to review the job profiles and individual goals in accordance with changes in the organization's activities.

A prerequisite for monitoring individual performance is to provide feedback in the process of managing performance. It allows you to determine the achievements of an employee or identify weak points that need improvement or development.

The traditional approach to staff assessment is focused on an individual, while nontraditional involves evaluating within a group interaction. The performance evaluation system should be based on quality information and reasoned opinions; the assessment procedure must be clear, transparent and accessible to workers with an opportunity to appeal the assessment.

Key words: individual performance, manager, monitoring, organization, evaluation, employee, process, result, system, management, goals.

\section{Постановка проблеми}

Сьогодні професійний менеджмент $є$ основною конкурентною перевагою організації та спрямований на забезпечення ii результативності та ефективності. Управління результативністю організації є однією з головних функцій професійної діяльності новітніх українських менеджерів, успішна реалізація якої потребує концептуального бачення та прикладних механізмів використання менеджерами методології управління результативністю, зважаючи на конкретні умови та обмеження середовища діяльності. Управління вітчизняними організаціями буде результативним та ефективним на практиці тільки за умови методично грамотного виокремлення ключових етапів, операцій та процедур процесу управління індивідуальною результативністю працівників, системного характеру ії оцінювання та оптимізації управлінських рішень, адекватних поставленим цілям.

Оцінювання результативності $\epsilon$ істотним елементом процесу управління результативністю: він завершує процес, даючи відповіді на ключові питання результативності: “чи добре ми працюємо?” і “чи добре ми попрацювали?”. Головний наслідок еволюції управління результативністю за останнє десятиліття - це увага не тільки до цілей, але і до засобів. Підвищення результативності та розвиток персоналу неможливі без розуміння не тільки того, що? потрібно зробити, але і як?, що і визначає актуальність досліджуваної проблеми.

Аналіз останніх досліджень і публікацій

Наукові дослідження питань результативності представлені ширше у працях зарубіжних вчених. Зокрема, фундаментальний підхід до управління результативністю та ефективністю організацій висвітлено в роботах: М. Армстронга, В. Білошапки, П. Друкера, Н. Энди, Р. Каплана, Г. Кокінза, П. Кругмана, Д. Лафта, Д .Нортона, Д. Сінка, Б. Фелпса, П. Самуельсона, В. Шапіро. В новітній Україні теоретичні та методологічні засади формування системи показників оцінки ефективності та результативності організацій є предметом наукових досліджень учених: О. Березіна, О. Виноградової, Є. Горчакової, О. Козирєвої, О. Кузьміна, Й. Петровича, Ф. Поклонського, В. Стадник, Н. Терещенко, А. Тищенко , Л. Федулової, Ф. Хміля, Н. Яшина.

Втім, незважаючи на значний науковий доробок зарубіжних вчених, українські науковці мало дослідили процес управління результативністю, резерви ефективного використання управлінських ресурсів для підвищення індивідуальної результативності працівників та організації загалом. Немає 
теоретичних розробок і практичних рекомендацій з питань процесного управління результативністю сучасних організацій. Тому сьогодні $є$ цілком очевидною $є$ потреба в уточненні та систематизації концептуальних засад та методичних інструментів моніторингу індивідуальної результативності працівників у процесі управління організацією

\section{Постановка цілей}

Під час дослідження передбачається вивчення та узагальнення наукових підходів щодо ролі та змісту моніторингу індивідуальної результативності працівників у процесі управління організацією.

\section{Виклад основного матеріалу}

Управління результативністю організації неперервний процес, який логічно охоплює дії та процедури лінійного менеджера в єдиний ланцюг за логікою осмисленої діяльності: від формулюваня цілей до контролю досягнутих результатів. Як зазначає Річард Ю. Зоді у праці “Бюджетування результативності”, оцінювання результативності працівників є істотним елементом управління результативністю: вона завершує процес, даючи відповіді на ключові питання результативності: “чи добре ми працюємо?" і “чи добре ми попрацювали?” [1, с. 37].

На думку авторів концепції управління результативністю М. Армстронга, А. Берон та їхніх послідовників, система оцінювання індивідуальної результативності передбачає постійний моніторинг результативності, який повинен орієнтуватися на узгоджені завдання, плани робіт, розвиток персоналу організації та удосконалення іï бізнес-процесів [2, с. 25]. Більшість учених вважає, що процес постійного моніторингу визначає проведення неформальних обговорень досягнутих результатів, формальні проміжні перевірки, офіційні атестації.

Управління індивідуальною результативністю, зокрема, і іiі моніторинг, повинен здійснюватися на основі угоди між менеджером і співробітником. Угода описує цілі роботи співробітника i способи вимірювання результатів цієї роботи. В угоді про результативність фіксується узгоджений напрямок розвитку і формується основа для вимірювань, зворотного зв'язку, оцінки та розвитку співробітників у процесі управління результативністю. В угодах формулюються очікування результати, які повинні бути досягнуті, і навички, знання та досвід, необхідні для їх досягнення. На цьому етапі узгоджують, за якими критеріями буде оцінюватися результативність і які фактичні дані слугуватимуть основою для визначення рівнів компетенцій. Дуже важливо задати й узгодити ці критерії на етапі планування результативності працівника.

Очікування мають чітко визначатися й узгоджуватися у формі посадових профілів. У профілі потрібно описати поточні завдання у вигляді вимог до кожної суттєвої складової роботи в тій чи іншій посаді. Також ставляться цілі, від короткострокових до середньострокових, щодо розширення навичок і знань, відповідності ключовим цінностям організації та виконання вимог до поведінки співробітника. Все це можна загалом охарактеризувати як завдання. Як бачимо, це щось більше, ніж визначення кінцевих цілей “на виході”, як багато хто вважає.

Досить часто профіль посади плутають із посадовою інструкцією. Вони справді мають деякі подібні структуротворчі елементи, але ототожнювати їх не можна. Посадова інструкція часто має більше формальний характер, iї наявність передбачена нормативно-правовими актами трудового законодавства України. Традиційно вона містить розгорнутий перелік прав, обов'язків і відповідальності на певній посаді, а також загальні вимоги до досвіду та освіти працівника. Розробляють iï для посади, а не індивідуально для працівника.

Профіль посади - це локальний документ, яким оперують як оцінним інструментом під час підбору, оцінювання, навчання, розвитку і ротації персоналу. Він $є$ повною картиною посади та працівника, який зможе ії зайняти. Структурно, крім посадових обов'язків, основними елементами профілю посади є:

ß кваліфікаційна карта - це опис вимог до освітньо-кваліфікаційного рівня кандидатів: навчальний заклад, рівень освіти, спеціальність і кваліфікація, знання іноземних мов, володіння певним пакетом програмного забезпечення тощо; 
ß карта компетенцій - перелік професійних та особистісних характеристик, навичок, здібностей, стилю мислення, моделей поведінки, необхідних для якісного виконання зазначених обов'язків;

ß біографічні дані - стать, вік, місце проживання та ін.

Спеціалісти 3 менеджменту персоналу радять також до профілю посади долучити опис порядку взаємодії співробітника з колегами під час виконання своїх обов'язків (які питання і з ким мають вирішуватися/погоджуватися), відповідно до типу організаційної структури управління, що відображає ієрархічні та функціональні взаємні зв'язки.

Під час оцінювання персоналу профіль посади менеджерам потрібно використовувати для визначення рівня відповідності співробітника займаній посаді, його потенційних можливостей. Тобто, порівнявши набір компетенцій працівника в момент його прийняття на роботу і в момент оцінювання, можна говорити про потенціал, здібності до навчання, можливості для розвитку. Виходячи 3 цього, в організаціях повинен розроблятися план навчання персоналу, формуватися кадровий резерв і відбуватися кадрові переміщення.

Структура і зміст профілю посади не бувають стандартними і статичними. Так, одна й та сама посада в різних компаніях часто має різний профіль. Окрім того, в межах однієї організації вони можуть змінюватися і відрізнятися для однакових посад під впливом зовнішніх і внутрішніх чинників. Приклад погодження посадових функцій та очікувань щодо співробітника наведений у табл. 1.

Таблиия 1

\section{Приклад погодження посадових функцій та очікувань працівників (адаптоване до джерела [2, с. 45])}

\begin{tabular}{|c|c|}
\hline $\begin{array}{l}\text { Питання, що } \\
\text { узгоджуються }\end{array}$ & Можливі варіанти відповідей \\
\hline Навіщо? & $\begin{array}{l}\text { Відповідь на це питання дає колегам чітке уявлення про те, чого від них очікують і } \\
\text { як цього досягти. }\end{array}$ \\
\hline Коли? & $\begin{array}{l}\text { Приблизно на початку року, регулярно, щоб відстежити зміни на організаційному } \\
\text { та індивідуальному рівнях - у бізнес-задачах, посадах, потребах розвитку. }\end{array}$ \\
\hline Як? & $\begin{array}{l}\text { У процесі обговорення між співробітником і його лінійним керівником } \\
\text { узгоджуються очікування щодо всіх складових роботи (включно } 3 \text { практичними } \\
\text { результатами діяльності і стилем поведінки). }\end{array}$ \\
\hline Що? & $\begin{array}{l}\text { Встановлюються очікування, пов'язані } з \text { посадою, для чого використовуються } \\
\text { посадові профілі, індивідуальні посадові інструкції, конкретні бізнес-завдання: } \\
\text { B у зв'язку з цим аналізують результативність кожного співробітника; } \\
\text { B } \\
\text { Виявляються/узгоджуються проблемні зони, які потребують поліпшення; } \\
\text { В досягнуту угоду документує працівник і затверджує лінійний керівник; } \\
\text { Вбговорюється, як вимоги будуть формулюватися, супроводжуватися під } \\
\text { час роботи і оцінюватися. }\end{array}$ \\
\hline
\end{tabular}

Протягом усього року, особливо під час проміжних перевірок, потрібно переглядати посадові профілі й індивідуальні цілі відповідно до змін у діяльності організації.

На думку російського вченого А. Я. Кібанова, “...атестаційне оцінювання персоналу організації (підрозділу) - це спеціальні (безперервні або ті, що періодично проводяться) формалізовані заходи, в межах яких оцінюється сам працівник, його праця і результат діяльності, атестаційна оцінка акумулює результати роботи конкретних співробітників за певний період. Тут відбувається не порівняння їх між собою, а зіставлення зі стандартом роботи (порівнювати можна тільки те, наскільки один співробітник більше/менше відповідає вимогам, ніж інший” [3, с. 71].

Формальні атестації - це моменти максимального зосередження менеджерів на найважливіших питаннях мотивації, продуктивності, розвитку співробітників. Вони дають можливість співробітникам обміркувати над найважливішими проблемами особистісного зростання i 
підвищення власної результативності. Це можливість діалогу - двосторонньої комунікації під час якої формується основа майбутніх планів робіт і розвитку персоналу організації. Формальні атестації $\epsilon$ важливим елементом управління результативністю, доповнюють та підкріпляють неформальні або проміжні обговорення досягнутих працівниками результатів. Окрім того, формальні атестації дозволяють ранжувати співробітників за результативністю з метою оплати їх праці відповідно до внеску.

Вивчення та узагальнення наукових праць зарубіжних вчених з питань оцінювання індивідуальної результативності працівників організації дозволяе нам констатувати, що у практиці зарубіжного менеджменту атестація співробітників за результативністю переслідує декілька цілей:

ß мотивацію: забезпечення позитивного зворотного зв'язку, визнання і винагорода, створення умов для подальшого професійного зростання; інформування співробітника про очікувані від нього результати; надання працівникам можливості самим контролювати власну результативність та розвиток;

ß розвиток: створення основи для розвитку й розширення у працівника можливостей виконувати роботу і на теперішній посаді, і на будь-якій іншій, яку він у перспективі міг би зайняти. Варто зазначити, що цей розвиток може стосуватися його поточної зайнятості, що дозволяє співробітникові розширити і збагатити сферу своєї відповідальності, вдосконалити наявні навички і домогтися відповідної винагороди. Цей бік розвитку набуває особливого значення в плоских організаційних структурах управління, де кар'єрна драбина коротка, і будь-яке відхилення часто $€$ найшвидшим шляхом наверх;

ß комунікацію: створення двостороннього каналу обговорення посадових функцій, очікувань, взаємин, професійних проблем і прагнень.

Крім того, атестації можуть послужити основою для ранжування співробітників за результативністю, особливо якщо рейтинги потрібні для відрядної оплати праці $[2,4]$.

Варто зауважити, що аналогічні цілі переслідує і атестація персоналу на вітчизняних організаціях та підприємствах. Проте дещо інакше їх інтерпретують вітчизняні вчені в царині менеджменту персоналу. Так, у наукових працях українських учених блок цілей розвитку підмінюється групою цілей адміністративного характеру, що віддзеркалює пережитки адміністративно-командної системи управління. В працях більшості українських науковців виокремлюють також три групи цілей: адміністративну, інформаційну, мотиваційну. За сутністю вони переплітаються з розглянутими нами вище, проте, на нашу думку, правильнішим є їх трактування в зарубіжному менеджменті, оскільки там вони повніше віддзеркалюють призначення атестації персоналу в процесі управління результативністю.

Утім, не дивлячись на несуттєві розбіжності в підходах зарубіжних і вітчизняних учених, досягнення цілей атестації можливо тільки у разі дотримання менеджерами таких принципів, як: об'єктивність, доступність, гласність, результативність.

У фаховій науковій літературі з менеджменту персоналу вчені достатньо системно і грунтовно висвітили питання щодо процедури та алгоритму оцінювання індивідуальної результативності персоналу. Зокрема, російський науковець В. Веснин рекомендує для організації ефективної системи оцінювання результативності праці лінійним менеджерам:

B встановити стандарти результативності праці для кожного робочого місця та критерії іï оцінювання;

ß виробити політику проведення оцінювання результативності праці (коли, як часто і кому проводити оцінювання);

ß зобов'язати певних осіб здійснювати оцінювання результативності праці;

B зобов'язати осіб, що проводять оцінювання, збирати дані про результативність праці;

ß обговорити оцінку з працівником;

ß прийняти рішення і задокументувати оцінку [6, с. 76].

Інформаційним забезпеченням системи атестаційного оцінювання персоналу повинні бути три групи даних: що оцінюється (результати, поведінка); як оцінюється (процедури); за допомогою чого оцінюється (методи). Коли йдеться про фіскальну результативність, для відповіді на ці 
запитання необхідно провести оцінювання різноманітних даних. Існування даних залежить від ретельності роботи орієнтованого на результат керівника, зазначає Р. Зоді [1, с. 35].

Оцінювання індивідуальної результативності працівників науковці рекомендують розпочинати з ретроспективного аналізу результатів і причин досягнення певного рівня результативності. Результати потрібно порівняти 3 узгодженими цільовими показниками. Під час аналізу причин варто враховувати ситуацію (системне оточення), інакше кажучи ставиться запитання: "Чи можна пояснити отримані результати впливом факторів, непідконтрольних цьому співробітнику?”. Далі потрібно проаналізувати всі індивідуальні поведінкові фактори, які могли вплинути на результати. Водночас визначальними чинниками є якість керівної роботи менеджерів та їх зацікавленість у розвитку своїх підлеглих. Найкраще проводити поведінковий аналіз з використанням моделі компетенцій і фактичних даних - прикладів справжньої поведінки.

Найпоширенішими методами оцінювання персоналу є методи: анкетування, описового оцінювання, класифікації, попарного порівняння, рейтингу, “360 градусів”, заданого розподілу, оцінювання за вирішальною ситуацією. Ці методи в традиційному підході найкращі в комплексному дослідженні.

У практиці зарубіжного менеджменту набув поширення матричний чи графічний метод оцінювання результативності працівників. Лінійний менеджер і працівник, що атестується, спільно вирішують, де перебуває останній у матриці або сітці результативності, зображеній на рис. 1.

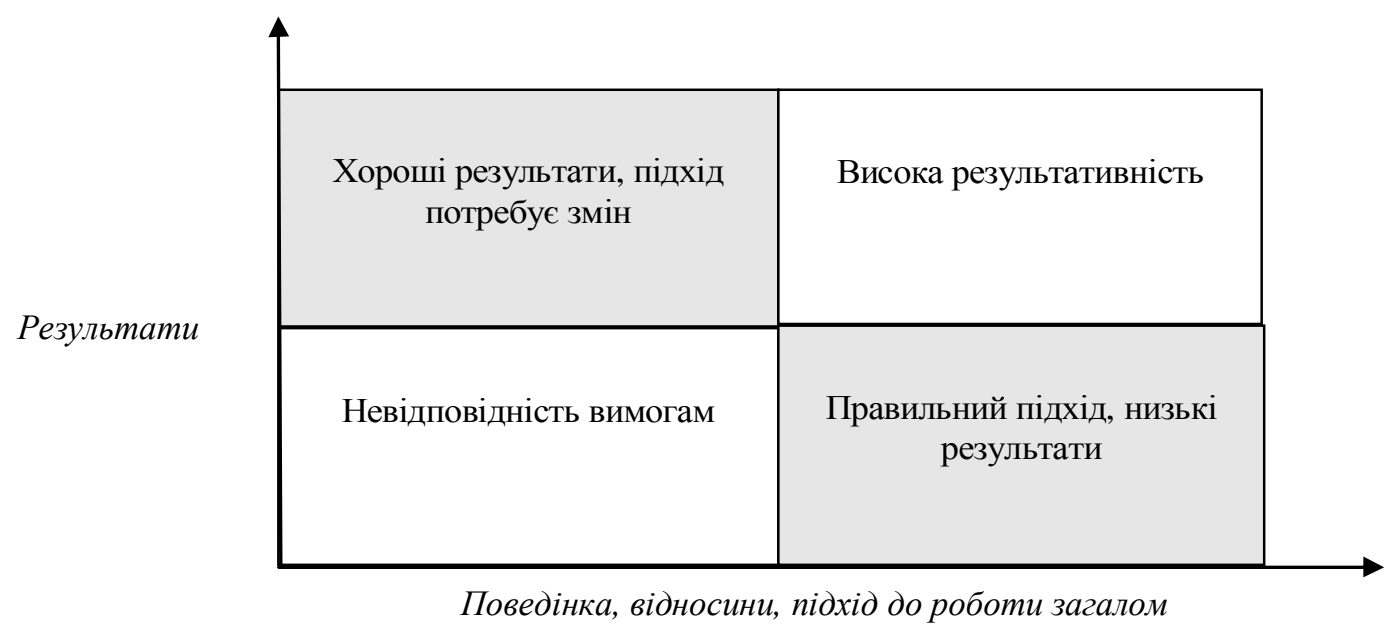

Рис. 1. Матриия результативності персоналу

Сітка в бланку щорічної атестації працівника за результативністю є важливим інструментом, який допомагає зробити “моментний знімок" його сукупного внеску. Оцінка індивідуального внеску враховує і результати, і поведінку, ставлення до справи, підхід до роботи загалом. У бланку оцінки результативності повинно бути відображено, яке місце відвів працівнику лінійний менеджер у матриці. Оцінювання повинно враховувати те, як виконує працівник вимоги, що висуваються до посади, зафіксовані в посадовому профілі, досягнуті результати і розвиток компетенцій протягом року. Результати цього оцінювання мають стати основою для підвищення оплати праці в майбутньому.

Вчені рекомендують схожий “матричний” підхід застосовувати і під час оцінювання результативності менеджерів порівняно з менеджерами того ж рівня (рис. 2). Це не "оцінний рейтинг”. Призначення матриці - допомогти кожному зосередитися на тому, що у нього виходить найкраще, а також виявити всі проблемні області, які потребують поліпшення.

Матриця дозволяє розглянути одночасно два параметри - результати бізнес-діяльності і поведінку (стиль управління). Цим забезпечується всебічна оцінка внеску менеджера з урахуванням всіх посадових вимог і унеможливлюється короткостроковий фокус на поточних результатах. 


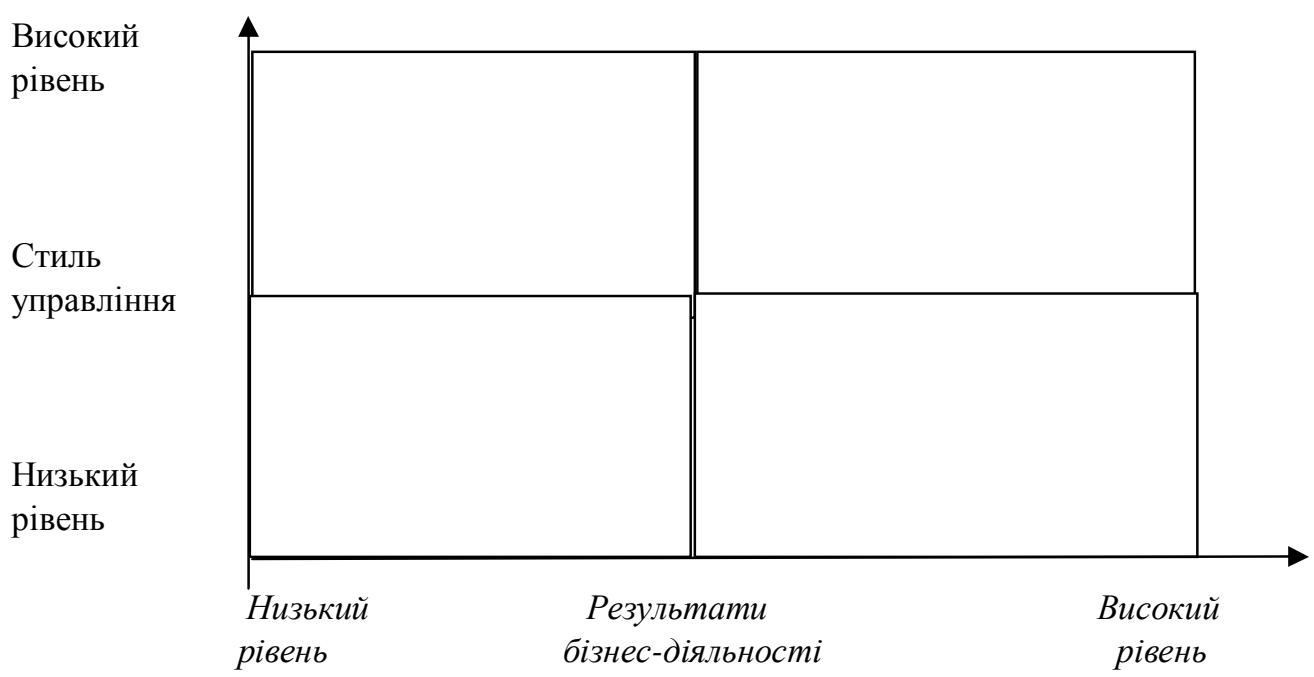

Рис. 2. Матриия результативності менеджерів

На думку і зарубіжних, і українських учених, необхідною передумовою моніторингу індивідуальної результативності є забезпечення зворотного зв'язку в процесі управління результативністю. Він дає змогу визначити досягнення працівника або виявити слабкі місця, які потребують поліпшення або розвитку. Основа зворотного зв'язку - фактичні дані: результати, події, критичні події, значимі вчинки, що зробили певний вплив на ефективність роботи. Зворотний зв'язок повинен здійснюватися на основі фактів, а не думок, і набувати форми, що дозволяє співробітникам визнати і прийняти іiі фактичну складову. Зрозуміло, факти можуть інтерпретуватися по-різному, але будь-яка інтерпретація повинна грунтуватися на реальній ситуації, що висвітлюється під час зворотного зв' язку, а не на суб'єктивних поглядах того, хто цей зв'язок забезпечує.

Потрібно вбудувати зворотний зв'язок у трудові процеси. Наскільки можливо, зворотний зв' язок повинен стати невіддільною частиною процесу управління результативністю. У працівників мають бути можливості та стимули оцінювати власну результативність [2, с. 67]. Під час дослідження нами доведено, що найбільш доцільним методом забезпечення зворотного зв'язку в процесі управління результативністю $є$ метод зворотного зв'язку “360 градусів”. Результати зворотного зв'язку є основою планування індивідуальної та групової результативності і використовуються менеджерами під час складання індивідуальних планів розвитку, що ще раз підтверджує циклічність процесу управління результативністю.

\section{Висновки}

Отже, традиційні схеми оцінювання досягнень співробітників грунтуються на ідеї програмноцільового управління. Співробітники спільно з менеджерами встановлюють цільові результати і показники ефективності та під час систематичних перевірок оцінюють і обговорюють прогрес, порівнюючи проміжні результати 3 цільовими. Головний наслідок еволюції управління результативністю за останнє десятиліття - це увага не тільки до цілей, але і до засобів. Рух в цьому напрямку диктувався простим міркуванням: підвищення результативності та розвиток персоналу неможливі без розуміння не тільки того, що? потрібно зробити, але і як?.

Традиційний підхід до оцінювання персоналу сфокусований на окрему людину, а нетрадиційний передбачає оцінювання в межах групової взаємодії, де в процесі імітації конкретної діяльності людина отримує можливість розкрити себе і свої здібності.

Лінійним менеджерам потрібно враховувати й етичний аспект управління результативністю, що розкривається найбільше в оцінці досягнутого рівня результативності. Тому система оцінювання результативності повинна грунтуватися на якісній інформації та аргументованих думках; процедура оцінювання має бути зрозумілою, прозорою і доступною для працівників 3 можливістю оскаржити оцінку. 


\section{Перспективи подальших досліджень}

3'ясування сутності та ролі моніторингу індивідуальної результативності в процесі управління результативністю має не тільки важливе теоретичне, але й практичне значення. Йдеться про те, що всебічне змістовне розуміння сутності моніторингу результативності працівників дасть змогу нам у подальших наукових дослідженнях:

B розкрити концептуальні засади провадження моніторингу результативності працівників сучасних вітчизняних організацій;

B сформувати систему інформаційного забезпечення моніторингу індивідуальної результативності працівників у сфері торгівлі, зважаючи на специфічні галузеві особливості;

ß озброїти лінійних менеджерів торговельних організацій і підприємств сучасними інструментами та методами оцінювання індивідуальної результативності;

ß обгрунтувати процедуру моніторингу індивідуальної результативності працівників торговельних організацій і підприємств.

1. Зоді Р. Ю., Лоуренс С. М., Лейсі Д. П. (1987) Бюджетування результативності. Інститут державного управління, Політехнічний інститут і Університет штату Вірджинія, Блексбер, 147 с. 2. Армстронг М., Берон А. (2014) Управление результативностью: Система оценки результатов в действии , Альпина Паблишер. 3. Кибанов А. Я. (2003) Управление персоналом организации, 483 с. 4. Измерение результативности компании (2007), Альпина Бизнес Букс, 220 с. 5. Кибанов А. Я., Баткаева И. А., Митрофанова Е. А., Ловчева М. В. (2009) Мотивация и стимулирование трудовой деятельности, М. : ИНФРА-М, 524 с. 6. Веснин В. Р. (2008) Управление персоналом. Проспект, 688 с.

1. Zodi R. Yu., Lourens S. M., Leisi D. P. (1987) Biudzhetuvannia rezultatyvnosti. Instytut derzhavnoho upravlinnia. Politekhnichnyi instytut i Universytet shtatu Virdzhyniia, Bleksber. 147 p. 2. Armstrong M. , Beron A. (2014) Upravlenie rezultativnostiu: Sistema otcenki rezultatov v deistvii. M. : Alpina Pablisher. 3. Kibanov A. Ia. (2003) Upravlenie personalom organizatcii. INFRA-M, 483 p. 4. Izmerenie rezultativnosti kompani.(2007) Klassika Harvard Business review. [2-e izd.]. M. : Alpina Biznes Buks. 220 p. 5. Kibanov A. Ia., Batkaeva I. A., Mitrofanova E. A., Lovcheva. M. V. (2009) Motivatciia i stimulirovanie trudovoi deiatelnosti. M. : INFRA-M. 524 p. 6. Vesnin V. R. (2008) Upravlenie personalom. M. : Prospekt, 688 p. 